\title{
Blood Pressure and Hemodynamics: Mayer Waves in Different Phases of Ovarian and Menstrual Cycle in Women
}

\author{
O. I. LUTSENKO ${ }^{1}$, S. O. KOVALENKO ${ }^{2}$ \\ ${ }^{1}$ Hlukhiv O. Dovzhenko National Pedagogical University, Hlukhiv, Ukraine, ${ }^{2}$ Cherkasy \\ B. Khmelnytsky National University, Cherkasy, Ukraine
}

Received February 1, 2016

Accepted August 5, 2016

On-line December 16, 2016

\section{Summary}

The goal of the research is to investigate the special effect of ovarian-menstrual cycle phases on the level of women's blood pressure and characteristics of Mayer waves. 77 women aged 18-19 were tested under condition close to the state of basal metabolism in follicular phase (I), ovulation (II) and luteal phase (III) of ovarian-menstrual cycle. In phases II and III, the increase of mean and diastolic blood pressure level, in comparison with phase I in the prone position at rest and with psycho-emotional loading, were observed. The distinctions between variation parameters of $R-R$ interval duration, stroke volume and its synchronization in phases II and III, in comparison with phase I, were observed in the prone position at rest, during tilt-test and with psycho-emotional loading. The substantial level of relationship between the power of Mayer waves and mean and diastolic blood pressure, mainly in phase I under conditions of all types, is observed. The maximum peak amplitude of stroke volume spectrogram is associated with pressure levels in the range of $0.04-0.15 \mathrm{~Hz}$ ( $\rho$ from -0.33 to -0.64$)$. The obtained results indicate the possible participation of spontaneous baroreflex sensitivity characteristics in keeping blood pressure level in women.

\section{Key words}

Blood pressure - Spontaneous baroreflex sensitivity - Mayer waves • Ovarian-menstrual cycle

\section{Corresponding author}

O. I. Lutsenko, Hlukhiv O. Dovzhenko National Pedagogical University, Kyiv-Moscow Street, 24, Hlukhiv, Sumy Region, Ukraine, 41400. E-mail: elenadvorchuk@mail.ru

\section{Introduction}

In $1876, \mathrm{~S}$. Mayer discovered slow waves in the oscillation of blood pressure (BP) at the frequency of $0.1-0.15 \mathrm{~Hz}$ in anesthetized rabbits. Later, the waves became known as "Mayer waves" (Cohen et al. 2013, Finucane et al. 2010). These waves are rather stable. In humans, they are located at a frequency of about $0.1 \mathrm{~Hz}$, which does not depend on gender, age and body position according to some investigations (Bertram et al. 2005). Later, similar oscillations for other hemodynamics indicators were found (R-R interval duration, stroke volume (BSV), etc.) (Cheng et al. 2004, Elstad et al. 2011). The level of spontaneous baroreflex sensitivity, an indicator associated with features of keeping BP, is determined in the range of frequencies close to Mayer waves (Finucane et al. 2010). However, the relationships of AP and the features of hemodynamics indicator oscillations in this range are investigated insufficiently.

At the same time, the indicators of heart rhythms variability (HRV) and central hemodynamics in different physiological conditions have some features stipulated by gender factors. The phase of ovarian and menstrual cycle (OMC) is found to have a sufficient effect upon HRV in the women of reproductive age both at rest and with various loading (Yildirir et al. 2002). Such effects are found to change sufficiently hemodynamics indicators stipulated mostly by hormonal changes during OMC. The relationships of AP and the features of Mayer waves have not been studied yet. 


\section{Methods}

77 women aged 18-19 were tested under the conditioned close to the state of basal metabolism in the prone position, at tilt test and during the test of psychicemotional stress (Makarenko 1999). All the women studied for humanitarian specialties at the Cherkasy National University. The main selection criteria were the lack of acute and chronic diseases, the normal trend of ovarian-menstrual cycle, the age of 17-19, the lack of taking hormonal contraceptives.

Each woman was tested three times: in follicular phase (I), ovulation (II) and luteal phase (III) of ovarianmenstrual cycle.

The women with regular ovarian-menstrual cycle took part in the study. Cycle phases were determined according to anamnesis, taking basal body temperature and using a set of inkjet ovulation tests "Solo" (IND Diagnostic, Inc., Canada). The confirmation of the reliability of cycle phase changes (optional) were performed by ultrasound diagnostics. Basal temperature taken rectally was increased by $0.5-0.8^{\circ} \mathrm{C}$ in luteal phase.

\section{Analytical methods}

Systolic and diastolic $\mathrm{BP}\left(\mathrm{BP}_{\mathrm{s}}\right.$ and $\mathrm{BP}_{\mathrm{d}}$, respectively) was measured with Korotkov auscultation method by mercury tonometer ("Riester", Germany). Mean blood pressure $\left(\mathrm{BP}_{\mathrm{m}}\right)$ was calculated with Hickam formula; struck volume (BSV) - with Kubichek formula (Kubichek et al. 1970) by the signals of differentiated impedance rheogram by all the realizations (beat-to-beat) during 5 min (Fig. 1).

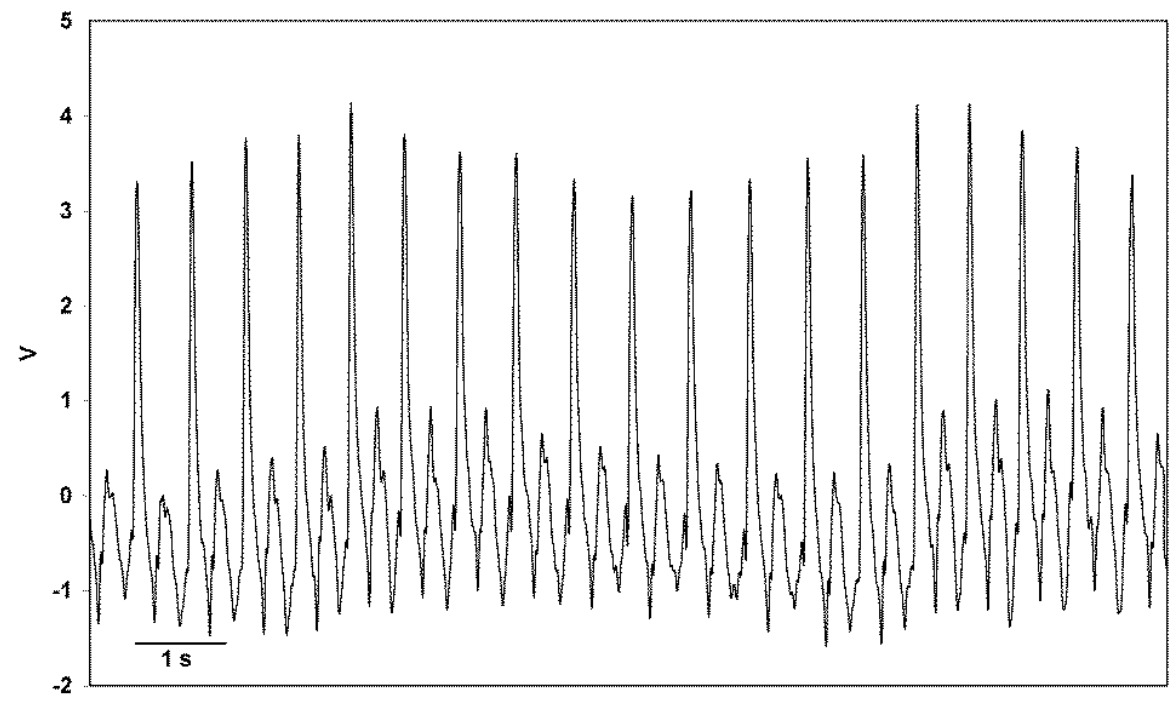

Fig. 1. Record fragment of differentiated impedance rheogram.

The spectral and cross-spectral analysis of cardiointervalogram was performed in "CASPICO" program (copyright certificate of Ukraine №11262) according to international standards of 1996 (Anonymous 1996). The power of R-R and BSV oscillations spectrum was calculated in standard frequency ranges of very low frequencies of $0-0.04 \mathrm{~Hz}$ (VLF), low frequencies of $0.04-0.15 \mathrm{~Hz}$ (LF), high frequencies of 0.15-0.4 Hz (HF), general oscillation power of $0-0.4 \mathrm{~Hz}(\mathrm{TP})$, normalized power in the range of $0.15-0.4 \mathrm{~Hz}\left(\mathrm{HF}_{\text {norm }}\right)$. Besides, spectral and cross-spectral density and the frequency of the highest amplitude oscillation peak of t-R-R and BSV in LF range (Kovalenko 2005) were estimated in the prone position at rest for 5-min records, at tilt test from the 2 nd till the 5 th minute and in psycho-emotional test from the 3 rd till 7 th minute.

\section{Statistical methods}

Due to the abnormality of the value distribution of oscillation power of hemodynamic indicators, their medians, the limits of 25 and 75 percentile were found; the average values and their errors for BP indicators distributed normally were determined. The reliability of differences between values in different OMC phases was estimated by means of Wilcoxon Paired Comparison and Student's t-test. The relationship between indicators was calculated by the nonparametric Spearman correlation coefficient (Glantz 2012).

\section{Results}

BP is known to be an important homeostatic indicator of an organism. Therefore, its changes in different $\mathrm{OMC}$ were analyzed in the prone position at 
rest, at tilt test and with psycho-emotional loading (Fig. 2). In the prone position at rest, $\mathrm{BP}_{\mathrm{m}}$ levels increased in phases II and III compared with phase I: the differences between phases I and II were $2.53 \pm 0.99$ $\mathrm{mm} \mathrm{Hg}(\mathrm{P}<0.05)$, between I and III $-2.76 \pm 1.24 \mathrm{~mm} \mathrm{Hg}$ $(\mathrm{P}<0.05)$. At tilt test, $\mathrm{BP}_{\mathrm{m}}$ increased in phases $\mathrm{I}$ and II, the changes were not significant statistically in phase III. Herewith, the difference of $\mathrm{BP}_{\mathrm{m}}$ was $0.78 \pm 0.97 \mathrm{~mm} \mathrm{Hg}$ in phase I-II and $1.55 \pm 0.87 \mathrm{~mm} \mathrm{Hg}$ in phase I-III.
$\mathrm{BP}_{\mathrm{m}}$ was leveled in phase III, compared with phase I, with psycho-emotional loading $(\mathrm{P}<0.05)$. Difference value of this $\mathrm{BP}_{\mathrm{m}}$ was $3.33 \pm 1.44 \mathrm{~mm} \mathrm{Hg}$ $(\mathrm{P}>0.05)$ and $2.74 \pm 1.16 \mathrm{~mm} \mathrm{Hg}$, respectively. Thus, $\mathrm{BP}$ response to such loading is characterized by definite features and, in all the phases, there is its increase in phase II and, especially, in phase III of OMC compared with phase I.

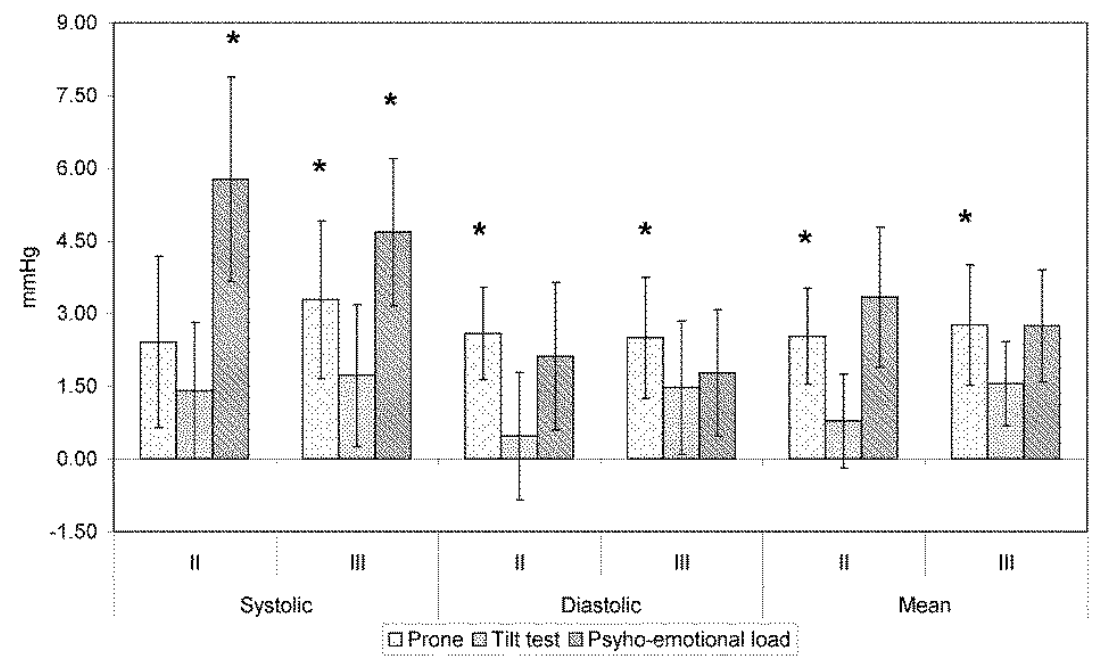

Fig. 2. Changes of systolic, diastolic and mean blood pressure in ovulatory (II) and luteal (III) phases of ovarian-menstrual cycle compared with follicular phase; $* \mathrm{P}<0.05$ compared to follicular phase.
The indicators of hemodynamic Mayer waves in women under different conditions are presented in Table 1. In the prone position at rest, oscillation power in the range of LF changed reliably in phase II (t-R-R) and in phase III (BSV) concerning phase I. Changing body position to a vertical one, the reactivity of t-R-R oscillation power was $27.6 \%[-35 ; 71.8]$ in this frequency range and differs significantly compared to phases I and II: $-1.4 \%[-35.6 ; 60.8]$ and $-21.7 \%$ [-59.2; 29.7], respectively.

The amplitude of maximum peak of $t-R-R$ and BSV waves also changed in different OMC phases. Thus, in the prone position at rest in women, there was significant $(\mathrm{P}<0.05)$ decrease of $\mathrm{t}-\mathrm{R}-\mathrm{R}$ oscillation density in phase III compared with phases I and II, and the increase of BSV oscillation density in phase II compared with phases I and III. With psycho-emotional loading, this indicator was the lowest in phase I of OMC (147.4 $\left.[81 ; 273.4] \mathrm{mc}^{2} \cdot \mathrm{Hz}^{-1}\right)$ compared with phases II and III 178.7 [103.8; 506.6] $\mathrm{mc}^{2} \cdot \mathrm{Hz}^{-1}$ and 207.2 [101.2; 408.7] $\mathrm{mc}^{2} \cdot \mathrm{Hz}^{-1}$, respectively.

The amplitude of the maximum peak of crossspectral power (maxLF) in the prone position at rest increased in phases II and III compared to phase I. At tilt test, the highest values were in phase I. Under the conditions of psycho-emotional loading, there was the greatest decrease of this indicator in phase II (-22.1\%) and III $(-40.8 \%)$ according to its background level of minor violations $(0.4 \%)$ in phase $\mathrm{I}$.

Thus, in the prone position at rest, at tilt test and with psycho-emotional loading, there are differences mostly in the indicators of R-R and BSV interval duration oscillations and their synchronization in women in phases II and III compared with phase I.

\section{Discussion}

$\mathrm{BP}$ is known to increase, in this case, due to the reduction of peripheral vessels in the lower limbs (Mohrman and Heller 2002). The mechanism of compensatory reaction to tilt test is due to the changes in the activity of baroreceptors in response to BP changes, the inhibition of vagus effect and the increase of sympathetic one on heart and blood vessels (Brunt et al. 2013).

The obtained reliable growth of BP value in phase III if compared to phase II and, moreover, to phase I shows the increased tone of ANS sympathetic part and agrees with literature data (Princi et al. 2005). Some authors (Vollebregt et al. 2006) indicate the individual features of autonomic regulation in women 
and suppose the relative stability of autonomous regulation type and its genetic determinism. However, there are some contradictions. Thus, Japanese scientists (Yamamoto et al. 2003) observed the increase of LF value reflecting the effect of both sympathetic and parasympathetic parts of ANS on BP level at both phase II and phase I.

Princi et al. (2005) found opposite data, i.e. LF increase in phase I and its decrease in phase III. However, only 6 women were examined, and therefore, these data are insufficient for statistic processing. Lucini et al. (2002) observed BP increase in phase II. Herewith, the content of sex hormones did not change. HRV indicators did not change in any OMC phase. However, the correlation between estrogen content and HRV absolute peak was identified in phase II. The authors explain the obtained correlation with cardiotropic effect of sex hormones.

The regulation of body functional systems in the classic sense is based on the phenomenon of receptor apparatus sensitivity. Anokhin (1962) showed that it was receptors that played a key role in the regulation of functional systems as a component of biosystem. According to the author, the system has infinite opportunities to align adaptive effect due to the innate specific features of receptors and their relationship with "working body".

The features of hemodynamic Mayer waves are found to reflect the level of spontaneous baroreflex sensitivity, which stipulated the stability of BP (Vallais et al. 2009). Therefore, the relationship between these indicators has been analyzed. Our results (Table 2) show the significant correlation between the power of Mayer waves and $\mathrm{BP}_{\mathrm{m}}$ and $\mathrm{BP}_{\mathrm{d}}$ mostly in phase I of OMC. The amplitude of maximum peak of BSV spectrogram in LF range is associated with the levels of $\mathrm{BP}_{\mathrm{m}}$ and $\mathrm{BP}_{\mathrm{d}}$ to a greater extent. This fact confirms the possibility of participating Mayer waves in keeping the level of system pressure in women.

Table 1. Indicators of Mayer hemodynamics waves in women under different conditions (median, limits of 25 and 75 percentile).

\begin{tabular}{|c|c|c|c|c|c|}
\hline \multirow[b]{2}{*}{ Phase } & \multicolumn{2}{|c|}{$\begin{array}{l}\text { Oscillation power in the range of } \\
0.04-0.15 \mathrm{~Hz}\end{array}$} & \multicolumn{2}{|c|}{$\begin{array}{c}\text { Amplitude of spectrogram maximum } \\
\text { peak in the range of } 0.04-0.15 \mathrm{~Hz}\end{array}$} & \multirow{2}{*}{$\begin{array}{c}\text { Amplitude of } \\
\text { maximum peak of } \\
\text { cross-spectral power } \\
\text { in the range of } \\
0.04-0.15 \mathrm{~Hz}, \mathrm{mc} \cdot \mathrm{ml}\end{array}$} \\
\hline & $\begin{array}{c}\text { R-R interval } \\
\text { duration, } \\
\text { mc }^{2} \\
\end{array}$ & $\begin{array}{c}\text { Stroke volume, } \\
\text { ml }^{2}\end{array}$ & $\begin{array}{c}\text { R-R interval } \\
\text { duration, } \\
\mathrm{mc}^{2} \cdot \mathbf{H z}^{-1}\end{array}$ & $\begin{array}{l}\text { Stroke volume, } \\
\qquad \mathbf{m l}^{2} \cdot \mathbf{H z}^{-1}\end{array}$ & \\
\hline \multicolumn{6}{|c|}{ Prone position } \\
\hline$I$ & $\begin{array}{c}612 \\
{[266 ; 832]}\end{array}$ & $\begin{array}{c}5.2 \\
{[2.2 ; 7.4]}\end{array}$ & $\begin{array}{c}14548 \\
{[6727 ; 23151]}\end{array}$ & $\begin{array}{c}279 \\
{[166 ; 737]}\end{array}$ & $\begin{array}{c}211 \\
{[114 ; 431]}\end{array}$ \\
\hline$I I$ & $\begin{array}{c}670 \\
{[273 ; 974]^{*}}\end{array}$ & $\begin{array}{c}6.1 \\
{[3.4 ; 7.2]}\end{array}$ & $\begin{array}{c}15979 \\
{[8686 ; 23902]}\end{array}$ & $\begin{array}{c}354 \\
{[135 ; 649]^{*}}\end{array}$ & $\begin{array}{c}289 \\
{[145 ; 753] *}\end{array}$ \\
\hline III & $\begin{array}{c}598 \\
{[241 ; 869]} \\
\end{array}$ & $\begin{array}{c}4.9 \\
{[3.1 ; 8.1]^{*}}\end{array}$ & $\begin{array}{c}11736 \\
{[5763 ; 24334]^{* \#}}\end{array}$ & $\begin{array}{c}292 \\
{[141 ; 528]^{\#}}\end{array}$ & $\begin{array}{c}258 \\
{[134 ; 445] *^{*}} \\
\end{array}$ \\
\hline \multicolumn{6}{|c|}{ Tilt Test } \\
\hline$I$ & $\begin{array}{c}523 \\
{[276 ; 771]}\end{array}$ & $\begin{array}{l}2.9 \\
{[1.9 ; 5.1]}\end{array}$ & $\begin{array}{c}12137 \\
{[7560 ; 23689]}\end{array}$ & $\begin{array}{c}326 \\
{[130 ; 462]}\end{array}$ & $\begin{array}{c}296 \\
{[111 ; 426]}\end{array}$ \\
\hline II & $\begin{array}{c}459 \\
{[276 ; 689]^{*}}\end{array}$ & $\begin{array}{c}3.2 \\
{[1.9 ; 4.4]}\end{array}$ & $\begin{array}{c}14331 \\
{[9427 ; 17804]^{*}}\end{array}$ & $\begin{array}{c}326 \\
{[139 ; 549]} \\
\end{array}$ & $\begin{array}{c}286 \\
{[140 ; 364] *} \\
\end{array}$ \\
\hline$I I I$ & $\begin{array}{c}553 \\
{[399 ; 867]}\end{array}$ & $\begin{array}{c}3.1 \\
{[1.6 ; 6.1]}\end{array}$ & $\begin{array}{c}13725 \\
{[10153 ; 17875]}\end{array}$ & $\begin{array}{c}254 \\
{[129 ; 628]^{\#}}\end{array}$ & $\begin{array}{c}266 \\
{[128 ; 401]^{\#}}\end{array}$ \\
\hline \multicolumn{6}{|c|}{ Psycho-emotional loading } \\
\hline$I$ & $\begin{array}{c}492 \\
{[300 ; 1047]}\end{array}$ & $\begin{array}{c}2.0 \\
{[1.1 ; 4.3]}\end{array}$ & $\begin{array}{c}12299 \\
{[8192 ; 23955]}\end{array}$ & $\begin{array}{c}147 \\
{[81 ; 273]}\end{array}$ & $\begin{array}{c}206 \\
{[133 ; 318]}\end{array}$ \\
\hline$I I$ & $\begin{array}{c}518 \\
{[341 ; 852]} \\
\end{array}$ & $\begin{array}{c}3.4 \\
{[1.8 ; 5.7]}\end{array}$ & $\begin{array}{c}12981 \\
{[9027 ; 21818]}\end{array}$ & $\begin{array}{c}179 \\
{[104 ; 507]}\end{array}$ & $\begin{array}{c}294 \\
{[133 ; 446]}\end{array}$ \\
\hline$I I I$ & $\begin{array}{c}425^{\#} \\
{[285 ; 605]}\end{array}$ & $\begin{array}{c}2.9 \\
{[1.6 ; 5.1]}\end{array}$ & $\begin{array}{c}10873 \\
{[6787 ; 14965]^{\#}}\end{array}$ & $\begin{array}{c}207 * \\
{[101 ; 409]}\end{array}$ & $\begin{array}{c}230^{\#} \\
{[138 ; 378]}\end{array}$ \\
\hline
\end{tabular}

\footnotetext{
* $\mathrm{P}<0.05$ compared with indicators in phase I; \# $\mathrm{P}<0.05$ between indicators in phases II and III.
} 
Table 2. Correlation of Mayer waves features and arterial pressure indicators in women in different phases of ovarian-menstrual cycle.

\begin{tabular}{|c|c|c|c|c|c|c|c|c|c|c|c|c|}
\hline \multirow{4}{*}{$\begin{array}{l}\text { Pressure } \\
\text { indicators }\end{array}$} & \multicolumn{6}{|c|}{$\begin{array}{c}\text { Oscillation power } \\
\text { in the range of } 0.04-0.15 \mathrm{~Hz}\end{array}$} & \multicolumn{6}{|c|}{$\begin{array}{l}\text { Amplitude of spectrogram maximum peak } \\
\text { in the range of } 0.04-0.15 \mathrm{~Hz}\end{array}$} \\
\hline & \multicolumn{3}{|c|}{$R-R$ interval duration } & \multicolumn{3}{|c|}{ Stroke volume } & \multicolumn{3}{|c|}{$R-R$ interval duration } & \multicolumn{3}{|c|}{ Stroke volume } \\
\hline & I & II & III & $\mathbf{I}$ & II & III & I & II & III & $\mathbf{I}$ & II & III \\
\hline & \multicolumn{12}{|c|}{ Prone position } \\
\hline Systolic & 0.01 & -0.13 & -0.10 & -0.14 & 0.00 & 0.11 & -0.03 & -0.14 & -0.10 & -0.33 & -0.16 & -0.45 \\
\hline Diastolic & -0.31 & -0.26 & -0.05 & -0.40 & -0.36 & 0.29 & -0.35 & -0.17 & -0.01 & -0.56 & -0.62 & -0.38 \\
\hline Mean & -0.10 & -0.24 & -0.01 & -0.27 & -0.22 & 0.23 & -0.15 & -0.18 & 0.04 & -0.46 & -0.49 & -0.46 \\
\hline \multicolumn{13}{|c|}{ Tilt Test } \\
\hline Systolic & -0.14 & 0.01 & -0.10 & 0.50 & 0.22 & -0.06 & -0.06 & 0.08 & -0.12 & -0.19 & -0.31 & -0.43 \\
\hline Diastolic & -0.48 & -0.25 & -0.28 & -0.23 & 0.12 & 0.29 & -0.40 & -0.14 & -0.41 & -0.64 & -0.34 & -0.38 \\
\hline Mean & -0.39 & -0.10 & -0.24 & 0.19 & 0.17 & 0.27 & -0.29 & -0.02 & -0.33 & -0.49 & -0.36 & -0.47 \\
\hline \multicolumn{13}{|c|}{ Psycho-emotional loading } \\
\hline Systolic & 0.14 & -0.28 & -0.20 & 0.25 & 0.18 & -0.08 & 0.09 & -0.24 & -0.14 & 0.161 & 0.008 & -0.197 \\
\hline Diastolic & -0.13 & -0.47 & -0.26 & -0.02 & -0.27 & -0.09 & -0.07 & -0.48 & -0.34 & 0.057 & -0.509 & -0.033 \\
\hline Mean & 0.05 & -0.33 & -0.36 & 0.17 & 0.04 & -0.19 & 0.047 & -0.32 & -0.38 & 0.216 & -0.212 & -0.414 \\
\hline
\end{tabular}

The classic definition of baroreflex sensitivity is based on an assessment of hemodynamic changes when epinephrine is injected (Chaswal et al. 2015). However, recently, the level of spontaneous baroreflex sensitivity has been determined in the investigation of human beings. Nowadays, the problem of interaction between baroreflex and BP in women under hormone action (during menstrual cycle) has not been decided. Sato et al. (1995) consider that spontaneous baroreflex sensitivity in women can disappear under the effect of sex hormones action. Moak et al. (2009) estimated HRV and spontaneous baroreflex sensitivity during their study of the features of autonomous nervous system under the conditions of normal menstrual cycle, and found that sympathetic tone increased in phase II compared with phase I. Brooks et al. (2012) determined that higher spontaneous baroreflex sensitivity and higher concentration of norepinephrine in the plasma of women were observed during phase III compared with phase I. The problem of what mechanism is in the basis of increasing the activity of ANS sympathetic part in phase III, remains debatable.

Limitations of the research are the following. First, the measurements were performed on a fairly limited (in age, social background) contingent. Second, the examined women had normal, for this group of people, blood pressure and, therefore, to carry the results to the individuals with its disorders is very problematic.
However, the results may be useful for understanding the etiology of hypertensive states.

\section{Conclusions}

In ovulatory and luteal phases of the ovarian cycle of women, the average and diastolic blood pressure was higher compared with the follicular phase at rest, in prone position and under the psycho-emotional loading. There are differences in the indicators of BSV and R-R interval duration oscillations and their synchronization in ovulatory and luteal phases in women compared with follicular phase in the prone position at rest, at tilt test and with psycho-emotional loading. There is a reliable correlation between the power of Mayer waves and mean and diastolic pressure mostly in OMC phase I of women under all the conditions. The amplitude of maximum peak of BSV spectrogram in the range of $0.04-0.15 \mathrm{~Hz}$ is associated with $\mathrm{BP}_{\mathrm{m}}$ and $\mathrm{BP}_{\mathrm{d}}$ to the greatest extent.

\section{Conflict of Interest}

There is no conflict of interest.

\section{Acknowledgements}

Research of the one of the authors (O. I. Lutsenko) was supported by the scholarship of Cabinet of Ministers of Ukraine for young scientists. 


\section{References}

ANOKHIN PK: General principles of formation of protective adaptation of the organism (in Russian). Vestn Akad Med Nauk SSSR 17: 16-26, 1962.

ANONYMOUS: Heart rate variability: standards of measurement, physiological interpretation and clinical use. Task Force of the European Society of Cardiology and the North American Society of Pacing and Electrophysiology. Circulation 93: 1043-1065, 1996.

BERTRAM D, ORÉA V, CHAPUIS B, BARRÈS C, JULIEN C: Differential responses of frequency components of renal sympathetic nerve activity to arterial pressure changes in conscious rats. Am J Physiol Regul Integr Comp Physiol 289: 1074-1082, 2005.

BROOKS VL, CASSAGLIA PA, ZHAO D, GOLDMAN RK: Baroreflex function in females: changes with the reproductive cycle and pregnancy. Gend Med 9: 61-67, 2012.

BRUNT VE, MINER JA, KAPLAN PF, HALLIWILL JR, STRYCKER LA, MINSON CT: Short-term administration of progesterone and estradiol independently alter carotid-vasomotor, but not carotid-cardiac, baroreflex function in young women. Am J Physiol Heart Circ Physiol 305: 1041-1049, 2013.

CHASWAL M, DAS S, PRASAD J, KATYAL A, FAHIM M: Restores baroreceptor-heart rate reflex and heart rate variability in rats with chronic nitric oxide deficiency. Physiol Res 64: 459-466, 2015.

CHENG Y, COHEN B, ORÉA V, BARRÈS C, JULIEN C: Baroreflex control of renal sympathetic nerve activity and spontaneous rhythms at Mayer wave's frequency in rats. Auton Neurosci 111: 80-88, 2004.

COHEN B, MARTINELLI GP, RAPHAN T, SCHAFFNER A, XIANG Y, HOLSTEIN GR, YAKUSHIN SB: The vasovagal response of the rat: its relation to the vestibulosympathetic reflex and to Mayer waves. FASEB $J$ 27: 2564-2572, 2013.

ELSTAD M, WALLOE L, CHON KH, TOSKA K: Low-frequency fluctuations in heart rate, cardiac output and mean arterial pressure in humans: what are the physiological relationships? J Hypertens 29: 1327-1336, 2011.

FINUCANE C, BOYLE G, FAN CW, HADE D, BYRNE L, KENNY RA: Mayer wave activity in vasodepressor carotid sinus hypersensitivity. Europace 12: 247-253, 2010.

GLANTZ SA: Primer of biostatistics. 7th edition, McGraw-Hill: Medical, New York, 2012, 320 p.

KOVALENKO SO: Analysis of the heart rhythm variability using median spectrogram method (in Ukrainian). Fiziol Zh 51: 92-95, 2005.

KUBICHEK WG, PATTERSON RP, WETSOL DA: Impedance cardiography as a noninvasive method of monitoring cardiac function and other parameters of the cardiovascular system. Ann NY Acad Sci 2: 724-732, 1970.

LUCINI D, NORBIATO G, CLERICI M, PAGANI M: Hemodynamic and autonomic adjustments to real life stress conditions in humans. Hypertension 39: 184-188, 2002.

MAKARENKO MV: A method for performing a study and assessment of the individual neurodynamic properties of human higher nervous activity (in Ukrainian). Fiziol Zh 45: 125-131, 1999.

MOAK JP, GOLDSTEIN DS, ELDADAH BA, SALEEM A, HOLMES C, PECHNIK S, SHARABI Y: Supine low-frequency power of heart rate variability reflects baroreflex function, not cardiac sympathetic innervation. Cleve Clin J Med 76: 51-59, 2009.

MOHRMAN DE, HELLER LJ: Cardiovascular Physiology. McGraw-Hill: Lange Medical Books, 2002, 257 p.

PRINCI T, PARCO S, ACCARDO A, RADILLO O, DE SETA F, GUASCHINO S: Parametric evaluation of heart rate variability during the menstrual cycle in young women. Biomed Sci Instrum 41: 340-345, 2005.

SATO N, MIYAKE S, AKATSU J, KUMASHIRO M: Power spectral analysis of heart rate variability in healthy young women during the normal menstrual cycle. Psychosom Med 57: 331-335, 1995.

VALLAIS F, BASELLI G, LUCINI D, PAGANI M, PORTA A: Spontaneous baroreflex sensitivity estimates during graded bicycle exercise: a comparative study. Physiol Meas 30: 201-213, 2009.

VOLLEBREGT KC, SEESING L, RANG S, BOER K, WOLF H: Sensitivity of spontaneous baroreflex control of the heart and hemodynamic parameters are not influenced by the menstrual cycle. Hypertens Pregnancy 25: 159-167, 2006.

YAMAMOTO M, TSUTSUMI Y, FURUKAWA K, KANNO Y, MARUYAMA R, SATOH H: Influence of normal menstrual cycle on autonomic nervous activity and QT Dispersion. Intern J Bioelectromagnetism 5: 152-153, 2003.

YILDIRIR A, KABAKCI G, AKGUL E, TOKGOZOGLU L, OTO A: Effects of menstrual cycle on cardiac autonomic innervation as assessed by the heart rate variability. Ann Noninvasive Electrocardiol 7: 60-63, 2002. 